\title{
INCUBATOR-BORNE PSEUDOMONAS PYOCYANEA INFECTION IN A NEWBORN NURSERY
}

\author{
BY \\ DINAH BARRIE \\ From the Department of Clinical Microbiology, Louis Jenner Laboratories, St. Thomas's Hospital and Medical School, \\ London
}

RECEIVED FOR PUBLICATION JANUARY 18, .1965)

In recent years, Pseudomonas pyocyanea and other Gram-negative bacteria have appeared more frequently as important pathogens. This has followed the effective antibiotic treatment of infections due to most other organisms and is also related to the increasing use of certain equipment which may become readily contaminated and which is difficult to sterilize. The problem is particularly serious in the neonatal period.

A small outbreak occurred in the premature baby unit of this hospital. During a period of three weeks, 4 babies were involved, of which the first, and most seriously affected, died. The aim of the present account is to re-emphasize the pathogenicity of Ps. pyocyanea, to describe the investigation and control of such an outbreak, and to suggest a routine for decontaminating incubators and other equipment.

\section{Case Reports}

Case 1. This baby, weighing 940 g. ( $2 \mathrm{lb} .1 \mathrm{oz}$.), was born after spontaneous premature labour at 29 weeks' gestation. He developed respiratory distress and was treated in an incubator with oxygen, penicillin, streptomycin, and intravenous dextrose. He improved initially, but by the ninth day his weight had fallen to $700 \mathrm{~g}$. (1 lb. 8 oz.) and frequent apnoeic attacks developed. Dextrose was again given intravenously with ampicillin and methicillin. On the following day he had a generalized pustular rash and a purulent discharge from one eye. The bacteriological findings (see Table 1) showed a wide-

TABLE 1

BACTERIOLOGICAL RESULTS OF CASE 1

\begin{tabular}{|c|c|c|}
\hline Day & Source & Results \\
\hline $\begin{array}{l}1 \\
10 \\
10 \\
12 \\
12 \\
12\end{array}$ & $\begin{array}{l}\text { Skin } \\
\text { Pharynx } \\
\text { Eye } \\
\text { Skin } \\
\text { Ankle } \\
\text { Skin }\end{array}$ & $\begin{array}{l}\text { Sterile } \\
\text { Very heavy growth of Ps. pyocyanea } \\
\text { Heavy growth of Ps. pyocyanea } \\
\text { Moderate growth of Ps. pyocvanea } \\
\text { Scanty growth of Ps. pyocyanea } \\
\text { Heavy growth of Ps. pyocyanea }\end{array}$ \\
\hline
\end{tabular}

spread Ps. pyocyanea infection. Intramuscular colomycin was started but his condition worsened rapidly and he died after only one dose had been given.

Case 2. This baby, weighing $1,160 \mathrm{~g}$. $(2 \mathrm{lb} .9 \mathrm{oz}$.$) ,$ was born after spontaneous premature labour at 27 weeks' gestation, and was resuscitated by endotracheal intubation and lung inflation. He was nursed in an incubator, and prophylactic penicillin and streptomycin were given. He made good progress until the eighth day when he developed conjunctivitis and an inflamed umbilicus, which was treated with erythromycin and

TABLE 2

BACTERIOLOGICAL RESULTS OF CASE 2

\begin{tabular}{|c|c|c|}
\hline Day & Source & Result \\
\hline 7 & Eye & $\begin{array}{l}\text { Mixed organisms including heavy } \\
\text { growth of Strep. faecalis }\end{array}$ \\
\hline 7 & Umbilicus & $\begin{array}{l}\text { Scanty growth of Ps. pyocyanea, } \\
\text { scanty growth of Staph. albus, } \\
\text { and moderate growth of Strep. } \\
\text { faecalis }\end{array}$ \\
\hline $\begin{array}{r}7 \\
20\end{array}$ & $\begin{array}{l}\text { Stool } \\
\text { Umbilicus }\end{array}$ & $\begin{array}{l}\text { No pathogens isolated } \\
\text { Single colony of Ps. pyocyanea, } \\
\text { scanty growths of Staph. aureus, } \\
\text { and Strep. faecalis }\end{array}$ \\
\hline 31 & Eye & Sterile \\
\hline
\end{tabular}

novobiocin while awaiting the bacteriological findings. These (see Table 2) indicated a mixed infection with Streptococcus faecalis, Ps. pyocyanea, and Staph. aureus. However, both infections cleared without further treatment and he made a complete recovery.

Case 3. This baby, a twin weighing $1,135 \mathrm{~g}$. (2 lb. $8 \mathrm{oz}$.), was born by forceps delivery at 29 weeks' gestation. He developed respiratory distress and was treated in an incubator with oxygen, penicillin, streptomycin, and intravenous dextrose. On the fourth day, he was lethargic and jaundiced, and the umbilicus appeared inflamed. A course of erythromycin and novobiocin was started but was changed to intramuscular colomycin when the bacteriological findings became available (see Table 3). The umbilicus was cleaned with hydrogen peroxide and sprayed with 'Polybactrin' (a solution con- 
TABLE 3

BACTERIOLOGICAL RESULTS OF CASE 3

\begin{tabular}{|c|c|c|}
\hline Day & Source & Result \\
\hline 4 & Umbilicus & $\begin{array}{l}\text { Heavy growth of } 2 \text { types of coli- } \\
\text { form organism }\end{array}$ \\
\hline $\begin{array}{l}7 \\
11 \\
11 \\
12 \\
18 \\
19 \\
21 \\
25 \\
29 \\
38\end{array}$ & $\begin{array}{l}\text { Umbilicus } \\
\text { Umbilicus } \\
\text { Stool } \\
\text { Umbilicus } \\
\text { Umbilicus } \\
\text { Stool } \\
\text { Stool } \\
\text { Stool } \\
\text { Stool } \\
\text { Stool }\end{array}$ & $\begin{array}{l}\text { Scanty growth of Ps. pyocyanea } \\
\text { Sterile } \\
\text { No pathogens isolated } \\
\text { Sterile } \\
\text { Sterile } \\
\text { No pathogens isolated } \\
\text { Scanty growth of Ps. pyocyanea } \\
\text { Scanty growth of Ps. pyocyanea } \\
\text { Scanty growth of Ps. pyocyanea } \\
\text { No pathogens isolated }\end{array}$ \\
\hline
\end{tabular}

taining neomycin, polymyxin $\mathrm{B}$, and bacitracin). Despite troublesome diarrhoea due to colomycin, his general condition improved and he recovered completely.

Case 4. This baby, weighing $1,800 \mathrm{~g}$. (4 lb.), was born by breech delivery at 35 weeks' gestation, the membranes having ruptured 12 days previously. Respiration was established after intubation and lung inflation. He was nursed in an incubator, and prophylactic penicillin and streptomycin were given. Apart from marked jaundice with a maximum serum bilirubin level of $19 \mathrm{mg} . / 100 \mathrm{ml}$. on the fifth day, his progress was satisfactory. In the course of investigating the outbreak, he was found to have a symptomless umbilical colonization with $P s$. pyocyanea, which rapidly cleared after spraying with Polybactrin.

\section{Method}

After the third case of Ps. pyocyanea infection had occurred, cultures were taken from all the babies in the nursery, the incubator, respirator, water manometer used in resuscitation, suction apparatus, scales, taps, hand disinfectant dispensers, unused disposable napkins, rubber bands used for cord occlusion, rubber tubing, and many other items in the nursery and labour wards. Swabs were first moistened in peptone water and were inoculated onto blood agar plates incubated aerobically at $37^{\circ} \mathrm{C}$. overnight. Ps. pyocyanea was identified by its typical colonies, odour, and Gram stain characteristics. The cytochrome oxidase test was used only if the organism did not fulfil these criteria. The antibiotic sensitivity pattern was determined for each specimen.

\section{Results}

All four incubators were contaminated with $P$ s. pyocyanea (see Table 4). The contamination occurred mainly on the plastic sleeves and was not found in the water of the humidifying reservoir. After cleaning the sleeves with soap and water and hypochlorite solution (Milton* 1:80), the organism was still present and sterile cultures were obtained only by completely removing all sleeve rims and steeping them in the hypochlorite solution.

Swabs taken from parts of the Bird respirator, which had been used to resuscitate the first baby, were sterile, but a moderate growth of Ps. pyocyanea was obtained from the face mask. The organisms were also isolated from two out of three resuscitation devices in the labour wards and the nursery; contamination was confined to the water and no organisms were recovered from the tubing. A blood agar plate was held at the position of the endo-

* Milton (Milton Pharmaceuticals Ltd.) is a proprietary preparation containing $1 \%$ sodium hypochlorite. A dilution of $1: 80$, giving 125 parts per million of hypochlorite, was used throughout.

TABLE 4

BACTERIOLOGICAL FINDINGS OF INCUBATORS

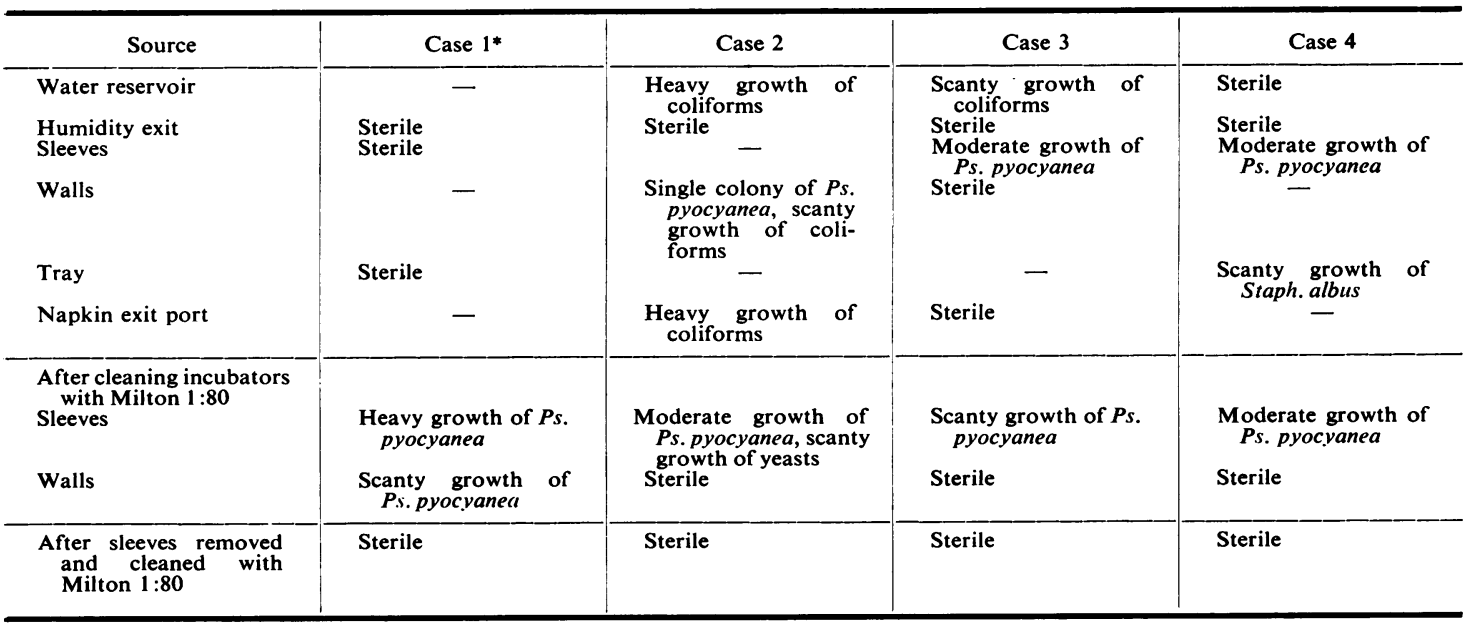

* This incubator had already been cleaned and returned into general circulation. 
tracheal tube and the device was operated for two minutes, but no organisms could be demonstrated despite an estimated 2.5 million $P$ s. pyocyanea organisms per ml. of water. This was as expected since the water column is used as a safety device for applying positive pressure, and there is no direct contact between the water and the patient.

Swabs of all other items were mostly sterile or had scant growths of non-pathogens.

\section{Discussion}

There are a disturbing number of reports of colonization and infection of newborn infants by $P s$. pyocyanea (Geppert, Baker, Copple, and Pulaski, 1952); Hoffman and Finberg, 1955); Asay and Koch, 1960). Laursen (1962) found that nasal contamination with $P$ s. pyocyanea occurred in $9 \%$ of infants in the premature nursery but in less than $0.3 \%$ of normal infants nursed with their mothers. Among the infants from whom Ps. pyocyanea was recovered, $90 \%$ had had oxygen therapy, almost invariably in incubators.

Common reservoirs of infection in nursery outbreaks include humidifiers, storage bottles, taps, wash-basins, and even the water used for bathing the infants' eyes. Sever (1959), in a bacteriological survey of the water in incubators and of storage bottles, found gross contamination with mean bacterial counts of up to 15,000 organisms per ml. which included Esch. coli, Alcaligenes faecalis, Achromobacter, Staph. aureus, Ps. pyocyanea, yeasts, and fungi.

Kresky (1964) found a 55\% colonization rate of babies by Gram-negative organisms. She devised a scheme for cleaning and disinfecting nursery equipment, using $1 \%$ Povidone iodine, as a result of which colonization of babies was reduced to $4.5 \%$, and contamination of equipment was virtually eliminated.

Experimental work on the influence of relative humidity on various organisms has shown different effects on survival. A relative humidity of $95-98 \%$ at $37^{\circ} \mathrm{C}$. allows an actual increase in the number of viable staphylococci, whereas a $55 \%$ relative humidity appeared to be the least favourable for their survival (McDade and Hall, 1963). However, Gram-negative organisms, such as Esch. coli and Serratia marcescens, have been similarly studied by Davis and Bateman (1960) who found moisture inhibitory to both, a relative humidity of $93 \%$ being more so than $75 \%, 11 \%$, or dry air. On the basis of the influence of humidity on the survival of organisms, Silverman (1964) has suggested that premature infants should be nursed at a relative humidity of only $50 \%$.
In the outbreak under review, management was directed first towards the immediate treatment of affected babies and those at risk, and secondly to the long-term problem of eliminating bacterial contamination of equipment, especially incubators. Affected babies were isolated, handling was reduced to a minimum, liberal use was made of sterile disposable gloves, special attention was paid to the incubator sleeves, and the unit was closed to further admissions. The major problem was that of cleaning and sterilizing incubators. These are now used extensively for nursing not only premature infants but also many sick infants, suffering from known infections such as gastro-enteritis and pneumonia. Fumigation with formalin vapour would seem the simplest, but its disadvantage is that prolonged airing is needed before re-use, and that it cannot sterilize the outer surfaces; the probable route of spread from incubator to incubator was by direct inoculation from the hands and arms of the attendants.

The plastic sleeves on the latest models of incubators have been replaced by sliding or hinged doors, though previous models are being used extensively. Fixed port doors are still vulnerable to bacterial contamination and require even more careful attention than removable parts.

Certain incubator manufacturers recommend the addition of antiseptics such as benzalkonium chloride to the water in the humidity reservoir. Objections to this are first that contamination, which was found to be centred on the plastic sleeves, would be unaffected by this manœuvre; in addition it is now well known that some organisms not only survive but actually multiply in many antiseptics.

In the scheme to be presented, hypochlorite solution (Milton 1:80), which already holds a timehonoured place in sterilizing feeding bottles and teats, was chosen for the incubators. Since the scheme has been in operation, no further infections with $P$ s. pyocyanea have occurred and bacteriological spot checks have shown treated incubators to be free from pathogens.

\section{Summary}

Four cases of Ps. pyocyanea infection in a premature nursery are described. A bacteriological survey showed the organisms to be present in the incubators, especially the sleeves. A practical scheme is outlined for eliminating such contaminants from incubators.

I am grateful to Dr. D. G. Cottom for permission to report cases under his care, and to Dr. Mark Ridley for helpful comments. 


\section{REFERENCES}

Asay, L. D., and Koch, R. (1960). Pseudomonas infections in infants and children. New Engl. J. Med., 262, 1062.

Davis, M. S., and Bateman, J. B. (1960). Relative humidity and the killing of bacteria. I. Observations on Escherichia coli and Micrococcus lysodeikticus. J. Bact., 80, 577.

Geppert, L. J., Baker, H. J., Copple, B. I., and Pulaski, E. J. (1952). Pseudomonas infections in infants and children. J. Pediat., 41, 555.

Hoffman, M. A., and Finberg, L. (1955). Pseudomonas infections in infants associated with high-humidity environments. ibid., 46, 626.
Kresky, B. (1964). Control of Gram-negative bacilli in a hospital nursery. Amer. J. Dis. Child., 107, 363.

Laursen, H. (1962). Incidence of Pseudomonas aeroginosa and other gram-negative rods in newborn infants. Acta obstet. gynec. scand., 41, 254.

McDade, J. J., and Hall, L. B. (1963). An experimental method to measure the influence of environmental factors on the viability and the pathogenicity of Staphylococcus aureus. Amer. J. Hyg., $77,98$.

Sever, J. L. (1959). Possible role of humidifying equipment in spread of infections from the newborn nursery. Pediatrics, 24, 50.

Silverman, W. A. (1964). Diagnosis and treatment: use and misuse of temperature and humidity in care of the newborn infant. ibid., 33, 276.

\section{Appendix}

The following scheme, duplicated on a single sheet, accompanies all incubators. A detailed description of the cleaning procedure is given on one side for the guidance of the nursing staff. The reverse side is in the form of a certificate which is intended to ensure that the full cleaning procedure has been carried out. An incubator is not used again until such a certificate has been completed and signed.

\section{Cleaning Procedure for Incubators \\ Part I \\ (Normally completed in the Ward)}

Incubators are often needed urgently. To ensure proper working order and to prevent infection being conveyed from one baby to the next, it is important that the following procedure be carried out meticulously after each baby and that Part $I$ of the Certificate is completed.

1. Enter the details of the last baby nursed in the incubator in the special history card for that incubator. This makes it possible to trace the sources of cross-infection.

2. Empty the water from the humidity reservoir by inverting the perspex filler on the front panel.

3. Remove the sleeves, wash them with soap and water, and then steep in Milton 1:80 solution for 1 hour. When the incubator is in use, this should be done daily as the sleeves are an important source of contamination and cross-infection.

4. Clean the perspex hood with warm water, soap, and $1 \%$ cetrimide.

(IMPORTANT: Perspex is destroyed by ether, acetone, and chloroform, and these must NEVER be used for removing stains. Adhesive plaster marks can be removed with spirit or 'Zoff'.)

5. Clean the mattress with warm water, soap, and $1 \%$ cetrimide. (NOTE: Never stick pins into the mattress when changing napkins. This perforates the waterproof cover and is a cause of cross-infection. If you see any perforations of the cover, discard and put on a new one.)

6. Using warm water, soap, and $1 \%$ cetrimide, clean the entire interior.

7. Boil any rubber tubing used.

\section{Part II}

1. Remove power unit.

(Normally completed by the Surgical Equipment Store)

2. Fill lower deck tanks with Milton solution 1:80 and leave for 1 hour.

3. Remove sleeve rims and steep rims and sleeves in Milton solution 1:80 for one hour.

4. Remove dirty filter and replace with a clean filter.

5. Wipe all parts (head, upper deck, humidity vent, mattress, cupboard, power unit, and flex) with Milton solution $1: 80$.

6. Air the incubator in a clean place. If an infant with a known infection has been nursed in the incubator, it should be aired for 24 hours, and, whenever possible, cleared by the Bacteriology Laboratory before re-use.

NOTE:

If the incubator is to be used for a new case without first being returned to the Surgical Equipment Store for sterilization, then all the routine steps carried out by them should be carried out on the Ward. 
1. Incubator history card entry made

2. Water emptied

3. Sleeves washed and sterilized

4. Hood cleaned

5. Mattress cleaned

6. Rubber ring, upper and lower decks cleaned

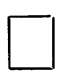

This incubator has been cleaned as above, prior to sterilization

Signed.

Date................

1. Power unit removed

2. Tanks sterilized with Milton

3. Sleeves and rims sterilized with Milton

4. Filter replaced

5. All parts cleaned with Milton

6. Incubator aired

This incubator has been cleaned with Milton as above, and is now ready for use.

Signed

Date.................

Immediately before use in the Ward

1. Wipe over

2. Fit sleeves

3. Fill humidity reservoir with sterile distilled water

4. Warm up

When a baby needs prolonged incubator care, the incubator should be changed weekly. 